\title{
Społeczeństwo w dialogu z żebrakami - idea i formy pomocy
}

\author{
Society in dialogue with beggars \\ - idea and form of help
}

\begin{abstract}
Abstrakt: Przedmiotem niniejszego artykułu będzie filozofia spotkania wybranych grup społecznych, jednostek z grupa wykluczonych - żebraków. Uwzględnione zostaną w tego rodzaju spotkaniu (spotkaniach) elementy pracy socjalnej, które są praktykowane $\mathrm{w}$ stosunku do ludzi żyjących z żebractwa przez instytucje państwowe, organizacje non-profit. Wskazane zostaną również elementy etyki, jakie towarzyszyły i towarzyszą tym spotkaniom.
\end{abstract}

Słowa kluczowe: dialog społeczny, filozofia spotkania, działalność opiekuńcza, margines społeczny, pomoc społeczna, żebracy.
Abstract: The subject of this article is the philosophy of the encounter of selected social groups, individuals with the excluded - beggars. In this kind of encounter (encounters) social work elements applied by state institutions and non-profit organisations in relation to people living off begging will be taken into consideration. Also elements of ethics accompanying such encounters will be indicated.

Keywords: social dialogue, philosophy of encounter, social care activity, underclass, social welfare, beggars. 
Ludzie od czasów tworzenia się wspólnot pozostają w sytuacji dialogu, który na różnych płaszczyznach funkcjonowania społecznego podtrzymuje więzi pomiędzy poszczególnymi jednostkami grupy mniej lub bardziej zorganizowanej. Z racji wyspecjalizowanych odmian dialogu, jaki zachodzi w relacji (-ach) międzyludzkiej (-ich), w różnych dziedzinach (antropologii, filozofii, psychologii itp.) rozróżnia się w XX wieku i na przełomie wieków XXXXI dialog - m.in. personalny, rzeczowy, egzystencjalny ${ }^{1}$, społeczny ${ }^{2}$, wychowawczy $^{3}$.

Zgodnie z jednym z nurtów filozofii współczesnej (zapoczątkowanym w latach dwudziestych XX wieku), tj. filozofią dialogu określaną mianem filozofii spotkania, u której podstaw tkwiła tradycja dialogiczna - dostrzeżony został człowiek w relacji „Ja - Ty"4 $\left(\right.$ Inny $^{5}$, Zapytany ${ }^{6}$ ). Jego podmiotowe traktowanie jako członka (-ów) rozmowy, sytuacji dialogowej pozwoliło w duchu teologicznym, etycznym rozpatrywać istotę ludzką. Rozszerzyło również dialektykę w rozumieniu platońskim na dialog w perspektywie etyczno-społecznej, na który wskazywali w swoich rozmyślaniach filozoficznych i wypowiedziach

1 Zob. rozumienie „pedagogiki dialogu” ks. Janusza Tarnowskiego - przedstawiciela filozofii personalistyczno-egzystencjalnej, w: J. Tarnowski, Pedagogika dialogu, w: Edukacja alternatywna. Dylematy teorii i praktyki, red. B. Śliwerski, Kraków 1992, s. 112-122.

2 Zob. rozumienie pojęcia dialogu społecznego, w: Konstytucja Rzeczpospolitej Polskiej z dnia 2 kwietnia 1997 (Dz. U. Nr 78, poz. 483); B. Barańska, M. Eichner, K. Hus, Dialog społeczny i tworzenie partnerstw na rzecz rynku pracy, Katowice 2011, s. 18; K. W. Frieske, Dialog społeczny i demokracja, w: Dialog społecznych na poziomie regionalnym. Ocena szans rozwoju, red. D. Zalewski, Warszawa 2005, s. 47; B. Abramowicz, Dialog społeczny w Polsce - instytucjonalizacja i praktyka, w: „Ruch prawniczy, ekonomiczny i socjologiczny” LXXI (2009), z. 4, s. 225-244.

3 Zob. M. Nowak, Dialog w wychowaniu, w: „Paedagogia Christiana” 25 (2010), nr 1, s. $85-103$.

4 Zob. nt. Martina Bubera i jego zasady dialogicznej, w: M. Buber, Ja i Ty. Wybór pism filozoficznych, wybór, tłum., wstęp J. Doktór, Warszawa 1992. Zgodnie z komentarzem Elżbiety Stawnickiej-Zwiahel można podać, że podstawą do filozofii dialogu u Bubera była Biblia hebrajska; zob. w: E. Stawnicka-Zwiahel, Człowiek wiary-godny w filozofii spotkania Martina Bubera, w: „Nauka - Etyka - Wiara” 2011, s. 370.

5 Emmanuel Levinas widział spotkanie $z$ Innym w przestrzeni etyki; zob. rozważania nt. Innego i etyki w rozumieniu Levinasa, w: S. Górzna, „Inny” w filozofii Emmanuela Levinasa, w: „Słupskie Studia Filozoficzne” 2012, nr 11, s. 57-70.

$6 \quad$ Józef Tischner rozpatrywał związek dialogiczny, który charakteryzuje człowieka w relacji do drugiego człowieka, którzy stają naprzeciw siebie jako Pytający i Zapytany. 
oficjalnych m.in. Jan Paweł II (Karol Wojtyła) ${ }^{7}$, Józef Tischner ${ }^{8}$, Franciszek (Jorge Mario Bergoglio) ${ }^{9}$.

Perspektywa etyczno-społeczna dialogu wpłynęła m.in. na spotkania ${ }^{10} \mathrm{z}$ drugim człowiekiem ${ }^{11}$ i doświadczenie „drugiego człowieka, który staje się źródłem prawdy o nas samych oraz sposobem identyfikacji i ubogacania własnego ja” ${ }^{\prime 2}$.

7 Zob. encykliki Jana Pawła II: Laborem exercens, w której zapisał m.in.: „[...] w dziedzinie pracy ludzkiej - solidarność, która nie może być zamknięta na dialog i na współpracę $\mathrm{z}$ innymi [...]. Dla realizacji sprawiedliwości społecznej w różnych częściach świata, w różnych krajach i we wzajemnych pomiędzy nimi stosunkach, potrzebne są coraz to nowe fronty solidarności ludzi pracy, a także solidarność z ludźmi pracy. Solidarność taka winna występować stale tam, gdzie domaga się tego społeczna degradacja podmiotu pracy, wyzysk pracujących i rosnące obszary nędzy, a nawet wręcz głodu”; Fides et ratio, w której pisał m.in.: „Myśl filozoficzna jest często jednym terenem porozumienia i dialogu z tymi, którzy nie wyznają naszej wiary [...] teren porozumienia i dialogu jest dziś szczególnie potrzebny dlatego, że najpilniejsze problemy ludzkości - wystarczy przytoczyć problem ekologiczny czy problem pokoju i współistnienia ras i kultur - mogą zostać rozwiązane dzięki lojalnej i uczciwej współpracy chrześcijan z wyznawcami innych religii oraz z tymi, którzy choć nie wyznają żadnej religii, szczerze pragną odnowy ludzkości.”; zob. w: Encykliki Ojca Świętego Jana Pawła II, Kraków 2009, s. 101, 770.

$8 \quad$ Ks. Józef Tischner w jednym z kazań rekolekcyjnych pt. Dialog ze współczesnym światem, powiedział m.in.: „[...] dialog to bardziej umiejętność słuchania niż umiejętność mówienia. Wydaje mi się, że współczesny człowiek potrzebuje przede wszystkim tego, żeby nam o sobie opowiedzieć. Ten człowiek, zagubiony w rozmaitych samotnościach, pragnie ubrać w słowa te swoje przeżycia. [...] znakomity punkt do naszego współczesnego dialogu ze światem. Jeśli czegoś nie wiemy, niech się nam przynajmniej nie wydaje, że wiemy.”; zob. J. Tischner, Nadzieja czeka na słowo. Rekolekcje 1966-1996, Kraków 2011, s. 143, 145.

9 Zob. omówienie głównych myśli papieża Franciszka, takich jak: włączenie społeczne ubogich, pokój i dialog społeczny, w: A. Sionek, Nic nam nie odbierze radości głoszenia, s. 20-29, w: http://www.enchristo.pl/wp-content/uploads/2014/05/Nic_nam_nie_odbierze_ radosci_gloszenia_Andrzej_Sionek_refleksja_nad_Evangellii_Gaudium.pdf (27.11.2016).

10 Za Martinem Buberem, który zapisał „Każde prawdziwe życie jest spotkaniem”, można przyjąć propozycję istoty spotkania; zob. więcej w: M. Buber, Ja i Ty. Wybór pism filozoficznych..., dz. cyt., s. 23-38.

11 O języku spotkania i problemach, jakie mogą zajść pomiędzy interlokutorami (np. wyjaśnienie: „Można być w języku spotkania mistrzem - poetą, który język kocha i dlatego sam poddaje się w nim najtrudniejszym próbom, jak i wyrobnikiem, który korzysta z codziennej mądrości wszelkiego rodzaju rozmówek uczących nas, jak z kimś kiedyś się spotkać lub jak się z kimś wreszcie raz na zawsze pożegnać. Zbyt często wydaje nam się, że tajemnice drugiego człowieka uda nam się rozwiązać za pomocą cytatu odziedziczonego po poprzednim spotkaniu."); zob. w: R. Kubicki, Trudny język spotkania, w: Dialog w żywiole wyobraźni, red. J. Stranz, Poznań 2008, s. 113 (Wyobraźnia dialogu, 1)

12 Zob. A. Bronk, A. Salamucha, Dialog jako droga do prawdy o człowieku, w: „Paedagogia Christiana” 25 (2010), nr 1, s. 23. 
Pozwoliła na skupieniu się na funkcji egzystencjalnej, personalistycznej ${ }^{13}$ dialogu społecznego i jego podmiotów. A w dalszej swej konsekwencji otworzyła jednostki, instytucje na potrzebę permanentnego dialogu ze wszystkimi członkami społeczeństwa, bez wykluczania tych, którzy stanowią margines społeczny ${ }^{14}$.

Okres XX wieku i początku XXI sprzyjał powolnemu, ale systematycznemu pochylaniu się (wykorzystując dobre praktyki kościelne, świeckie, państwowe poprzednich epok) w duchu etyczno-społecznym nad potrzebującymi pomocy - biednymi, wykluczonymi społecznie. Wśród osób i instytucji w bezpośredni sposób pracujących na rzecz inkluzji społecznej, w tym wspierania ubogich, włóczących się, żebrzących itp., wyróżniały się w pierwszych dziesięcioleciach XX wieku osoby świeckie i duchowne związane z polskimi kościołami, jak i instytucje powoływane do życia przez Kościół (np. Caritas ${ }^{15}$ ) oraz instytucje administracji publicznej, np. miejskie deputacje do spraw ubogich ${ }^{16}$. Wraz z upływem czasu do pomocy biednym, potrzebującym włączały się instytucje społeczne, gminne, wojewódzkie, państwowe. Pod koniec XX wieku rozwinęły swą działalność na rzecz potrzebujących organizacje non-profit ${ }^{17}$.

Przedmiotem niniejszego artykułu będzie filozofia spotkania wybranych grup społecznych, jednostek z grupą wykluczonych - żebraków. Uwzględnione zostaną w tego rodzaju spotkaniu (spotkaniach) elementy pracy socjalnej, które są

13 A. Bronk, A. Salamucha, Dialog jako droga..., dz. cyt.

14 Janusz Sztumski zdefiniował pojęcie marginesu społecznego. Według tego socjologa do zbioru ludzi określanych mianem marginesu społecznego zalicza się „ludzi przynależnych do rozmaitych kategorii lub grup społecznych, wyobcowanych w danym społeczeństwie na skutek nieosiągnięcia albo utraty przez nich względnie stabilnej pozycji, braku przystosowania do współżycia $z$ innymi, demoralizowanych lub zdegenerowanych pod względem psychofizycznym, ofiar dramatycznych zdarzeń losowych, niezaradnych i zagubionych oraz dyskryminowanych z różnych powodów itp., w: J. Sztumski, Systemowa analiza społeczeństwa, Katowice 2013, s. 121, 125.

15 Zob. ocenę działalności Caritasu Okręgu Poznańskiego na rzecz walki z żebractwem zawartą w piśmie wydawanym przez Wojewodę Poznańskiego z 20 czerwca 1927. Oto wybrane wyjątki z dokumentu podkreślające zasługi tego Towarzystwa na rzecz społecznego dobra, przestrzegania zasad etyki: „Poznański Okręg «Caritas» zorganizował akcję, mającą za zadanie wyłonienie elementu, niezasługującego na wsparcie, i oddanie go w ręce sprawiedliwości, zaś rzeczywiście potrzebującym zapewnienia wystarczających środków do życia. Pozatem pragnie «Caritas» uwolnić domy prywatne od plagi domokrążnego żebractwa względem możliwie uchronić swych obywateli przed natręctwem poszczególnych jednostek", w: Archiwum Państwowe w Poznaniu, Akta miasta Środy, sygn. 1447, Żebractwo i włóczęgostwo.

16 Zob. opieka nad ubogimi w tym żebrakami od 1796 w Poznaniu prowadzona była przez Dyrekcję Miejską, a później od 1928 przez Miejską Komisję Opieki Społecznej, w: W. Fidler, Historia Miejskiego Komitetu Walki z Żebractwem w Poznaniu, Poznań 1937, s. 8-10.

17 W Polsce działalność organizacji non-profit reguluje Ustawa z dnia 24 kwietnia 2003 r. o działalności pożytku publicznego i o wolontariacie (Dz. U. $2003 \mathrm{Nr}$ 96, poz. 873). 
praktykowane przez instytucje państwowe, organizacje non-profit w stosunku do ludzi żyjących z żebractwa. Wskazane zostaną również elementy etyki, jakie towarzyszyły i towarzyszą tym spotkaniom.

W państwach Zachodniej Europy oraz w Polsce działalność na rzecz inkluzji społecznej ludzi marginesu na przestrzeni dziejów ma swą tradycję. Niezaprzeczalny dialog pomiędzy wykluczanymi grupami społecznymi prowadził Kościół katolicki. Jego przedstawiciele już w okresie średniowiecza organizowali przytułki, szpitale itp. dla ubogich w miastach, np. starców, niepełnosprawnych, nierządnic, sierot, włóczęgów, żebraków. Zgodnie z uchwałą soboru nicejskiego z 325 roku powstawały zinstytucjonalizowane formy opieki nad potrzebującymi ${ }^{18}$. Pierwszymi takimi instytucjami były wskazane powyżej szpitale (szpitale jako przytułki), przytułki, sierocińce ${ }^{19}$, którymi opiekowali się zakonnicy reprezentujący: bractwo pod wezwaniem św. Jakuba (np. miasta Francji) ${ }^{20}$, czy też benedyktyni, bonifratrzy (np. Hiszpania, Polska) ${ }^{21}$, cystersi, franciszkanie, joannici ${ }^{22}$ itp.

Działalność charytatywna na rzecz ubogich $\mathrm{z}$ otwarciem na potrzeby tych ostatnich ze swej istoty tkwiła w założeniach i celach, które przyświecały Kościołowi jako organizacji i jego poszczególnym tworom istniejącym „wewnątrz istniejącego kościoła"23, czyli bractwom i zakonom ${ }^{24}$. Przykładowo zgodnie z istotą Bractwa Miłosierdzia założonego przez Piotra Skargę w Krakowie działania członków Bractwa miały być powodowane przykazaniami miłosierdzia, co potwierdza szesnastowieczny zapis: „Nędza żywota tego po wszystkich w świecie, po stanach wysokich i małych rozlała, za wolą Pana Boga dobrego, który inszą nam górną onę ojczyznę zgotowawszy, chce abyśmy tu na tej drodze tęsknili, a cierpliwością i miłosierdziem za łaskę jego do wiecznego się pokoju i rozkoszy cisnęli”25.

18 Por. H. Komarynska-Polak, Psychicznie chorzy w krakowskim szpitalu bonifratrów w XVII-XVIII wieku, w: Zeszyty Naukowe Małopolskiej Wyższej Szkoły Ekonomicznej w Tarnowie, 18 (2011) nr 1, s. 33; R. Suchenek, Instytucje kościelne w Poznaniu wobec żebractwa dzieci na przełomie XIX i XX wieku, w: „Język - Szkoła - Religia” 10 (2015), nr 3, s. 40.

19 Zob. więcej, w: B. Geremek, Ludzie marginesu w średniowiecznym Paryżu XIV-XV wiek, Poznań 2003, s. 143-152; A. Grzybowski, Szpitale dziewiętnastowiecznego Poznania, w: Kronika Miasta Poznania. Szpitale, Poznań 2007, nr 4, s. 41.

$20 \quad$ B. Geremek, Ludzie marginesu w średniowiecznym Paryżu..., dz. cyt., s. 154.

21 H. Komarynska-Polak, Psychicznie chorzy w krakowskim szpitalu..., dz. cyt., s. 36n.

22 H. Markiewiczowa, Rozwój społecznej działalności opiekuńczej na ziemiach polskich, w: „Seminare” 28 (2000), s. 275-276.

${ }^{23}$ J. Sztumski, Systemowa analiza społeczeństwa..., dz. cyt., s. 68.

24 Zob. więcej nt. w: J. Sztumski, Systemowa analiza społeczeństwa..., dz. cyt., s. 68.

25 Czytania Bractwa Miłosierdzia w Krakowie przy kościele Św. Barbary z dodatkiem Kazań o Miłosierdziu przez ks. Piotra Skargę, Kraków 1896, s. 225-251. 
Zakonne reguły wykształcone w okresie średniowiecza do czasów współczesnych obowiązywały i obowiązują. Pomoc niesiona ubogim, w tym żebrakom różnych okresów historycznych, była i jest stałym elementem działalności bractw i zakonów, na co wskazują: prowadzenie przytułków (w tym domów opieki, ochronek) do okresu końca II wojny światowej (zob. przykładowe instytucje: Dom Starców p.o. SS. Albertynek ${ }^{26}$, Ochronka S.S. Elżbietanek ${ }^{27}$, Przytułek dla Staruszek i Kalek Zgromadzenia SS. Serafitek w Oświęcimiu ${ }^{28}$ ), leczenie chorych (zob. np. Dom Chorych pod Samarytaninem ${ }^{29}$, Zakład medyczny u sióstr elżbietanek na Rybakach w Poznaniu; Zakład medyczny sióstr miłosierdzia w klasztorze po bernardynach w Poznaniu ${ }^{30}$, Szpital św. Józefa, czyli Dom Miłosierdzia dla dzieci przy ul. Ogrodowej w Poznaniu ${ }^{31}$, Śpital i kościół ś. Stanisława dla księży chorych i ubogich założony przez biskupa Jana Lubrańskiego $^{32}$ ), przekazywanie jałmużny ${ }^{33}$ (przez kościoły na rzecz ubogich, np. działalność w XIX wieku Stowarzyszenia przeciw żebractwu w Poznaniu ${ }^{34}$ ). Po roku 1945 Kościół katolicki w Polsce nie zaprzestał działań o charakterze charytatywnym. Wspierał przez ponad siedemdziesiąt lat biednych, potrzebujących wsparcia materialnego. Poprzez ciągłą działalność: Caritas (diecezjalnych, parafialnych), Towarzystw, zakonów, np. Zgromadzenie Sióstr Miłosierdzia św. Wincentego a Paulo, docierał i dociera z pomocą do rodzin najbiedniejszych (w tym żebraków, którzy na terenach przykościelnych, w budynkach kościołów, przy nich oczekiwali wsparcia od potencjalnych ofiarodawcó ${ }^{35}$ ).

Ofiarowanie pomocy materialnej, moralnej, medycznej biednym obszarów miejskich oraz wiejskich poprzez tworzenie instytucji pomocowych (zobacz wyżej wymienione instytucje działające na ziemiach polskich) stanowiło i stanowi wyraźny przejaw postawy otwartej stabilnych (prawnie, moralnie, gospodarczo) grup na potrzeby ludzi wypełniających margines społeczny. Z zastrzeżeniem tym-

\footnotetext{
26 Archiwum Państwowe w Krakowie, ZC, sygn. 71, Oświęcim.
}

27 Archiwum Państwowe w Poznaniu, Akta miasta Poznania, sygn. 3980, Statystyka. Opieka nad ubogimi.

28 APKr, ZC, sygn. 71, Oświęcim.

29 Archiwum Archidiecezjalne w Poznaniu, KA 15055, Akta schronisk-przytułków.

30 A. Grzybowski, Szpitale dziewiętnastowiecznego Poznania..., dz. cyt., s. 44.

31 A. Grzybowski, Szpitale dziewiętnastowiecznego Poznania..., dz. cyt s. 46.

32 J. Łukaszewicz, Śpitale $i$ inne dobroczynne zakłady i fundusze, w: Kronika Miasta Poznania. Szpitale..., dz. cyt., s. 22-23.

33 Od samego początku kształtowania się chrześcijaństwa - dawanie jałmużny było obowiązkiem wyznawców tej religii „zarówno świeckich, jak i duchownych”; zob. w: H. Markiewiczowa, Rozwój społecznej działalności opiekuńczej na ziemiach polskich..., dz. cyt., s. 275.

34 AAP, OA VIII 23, Stowarzyszenie przeciw żebractwu $i$ kolonia robocza $w$ Laskach Starych 1862-1893.

${ }_{35}$ Zob. więcej nt. miejsc i współczesnych sposobów pozyskiwania jałmużny, w: K. Król, Żebractwo we współczesnej Polsce jako kwestia społeczna, Konin 2010, s. 24, 106-122. 
że, że biorąc pod uwagę miłosierdzie, czynniki humanitarne, etyczne w rozdawnictwie datków, strona ofiarodawców, którą mogą być osoby prywatne i organizacje, musi poddać identyfikacji potencjalnych odbiorców jałmużny. Ten trudny proceder mający na celu eliminowanie z systemu gwarancji wsparcia (udzielanych przez organizacje kościelne, społeczne, socjalne) „pasażerów na gapę”36 powinien z założenia prowadzić do włączania do społeczeństwa „ludzi luźnych” poprzez dawanie im szansy zaistnienia na nowo w społeczeństwie. Takim działaniom byli poddawani i są poddawani przede wszystkim włóczędzy, żebracy.

Żebracy, jako grupa społecznie stygmatyzowana, byli w różnych okresach historycznych w Polsce w zróżnicowany sposób wspomagani przez ofiarodawców. Z racji wyspecjalizowanych grup żebraczych składających się z kobiet, dzieci itp., posługujących się różnymi technikami żebraczymi, występujących w różnych przestrzeniach miejskich ${ }^{37}$, wywoływali swoją obecnością ambiwalentne uczucia obserwujących ich. Nadto zaobserwowane nieuczciwe sposoby pozyskiwania jałmużny, natręctwo budziły społeczne niezadowolenie, a nawet lęk. Aby zaradzić niekontrolowanemu rozrostowi podgrupy „ludzi luźnych” - żebraków, podejmowano próby ich inkluzji do życia publicznego w postaci projektów, statusów $\mathrm{w}^{38}$, statutów organizacji, czy też zjazdu przeciwżebraczemu ${ }^{39}$. W projektach działań - np. Komisji Boni Ordinis (XVIII wiek) czy Stowarzyszenia przeciw żebractwu w mieście Poznaniu ${ }^{40}$ (późniejsze: Towarzystwo Walki z Żebractwem od listopada 1925 roku; Miejskiego Komitetu Walki z Żebractwem w Poznaniu ${ }^{41}$ ), zamierzano udzielać pomocy żebrzącym, $\mathrm{z}$ tym że pomoc ta miała być odgórnie

36 Por. Marginalność społeczna, w: Encyklopedia socjologii, t. 2, Warszawa 1999, s. 169.

37 Zob. techniki żebracze średniowieczne, w: B. Geremek, Świat „opery żebraczej”. Obraz włóczęgów i nędzarzy w literaturach europejskich XV-XVII wieku, Warszawa 1989, s. 200n; czy figury żebracze przyjmowane w XX i początku XXI wieku, w: K. Król, Żebractwo we współczesnej Polsce..., dz. cyt., s. 24n; S. Marmuszewski, J. Światłowski, Rola żebracza i jej ekspresja, w: Żebracy w Polsce, red. S. Marmuszewski, A. Bukowski, Kraków 1995, s. 131-142.

38 W piętnastowiecznym statucie piotrkowskim z 1496 zawarto artykuły nt. żebraków; zob. nadto komentarz do prawa miejskiego, Bartłomiej Groicki (cytowany za A. Karpińskim), zauważył m.in., iż „około żebraków w miasteczkach na dobrym rządzie bardzo schodzi, a wiele się pod tym żebraczym płaszczem złodziejstwa i innego łotrostwa zakrywa"; zob. w: A. Karpiński, Historycy wobec marginesu społecznego w Polsce XVI-XVIII wieku, w: Artykuły recenzyjne i recenzje, w: „Kwartalnik Historyczny” 1987, nr 2, s. 178.

39 Już w XV wieku (w 1496) w Polsce „ustanowiono prawo przeciw żebrakom i włóczęgom, na mocy którego wydano odznaki ubogim uprawnionym do żebrania”; zob. więcej w: Uzasadnienie, w: Archiwum Akt Nowych, Ministerstwo Opieki Społecznej, sygn. 54, Zwalczanie żebractwa i włóczęgostwa. Projekt ustawy 1925.

40 Zob. Status Stowarzyszenia przeciw żebractwu w mieście Poznaniu, w: AAP, OA VIII 23, Stowarzyszenie przeciw żebractwu i kolonia robocza w Laskach Starych 1862-1893.

${ }^{41}$ W. Fidler, Historia Miejskiego Komitetu Walki z Żebractwem w Poznaniu, Poznań 1937. 
ustalana przez organizację zgodnie z obowiązującymi w niej zasadami. Aby wyeliminować samo zjawisko żebractwa w XVIII wieku, projektowano „utworzenie przędzalni wełny, w której byliby zatrudnieni żebracy” ${ }^{42}$. Ich praca w przędzalni miała przywrócić ich społeczeństwu, dać im możliwość uczciwego zarobienia na swoje utrzymanie, jak również dania im szansy wyrównania swego stanu majątkowego.

Przykład Miejskiego Komitetu Walki z Żebractwem w Poznaniu (z jego historią sięgająca XIX wieku) poświadcza obecność idei dialogu pomiędzy grupami kupców poznańskich, przedstawicielami magistratu, kościoła mającego na celu dobro wyłączonych ze społeczeństwa - żebraków. Na mocy długofalowych działań zrealizowano kilka zamierzeń na rzecz żebraków - budowa: domu dla starców (1927 rok), w którym staruszki i starcy „zupełnie niezdolni do jakiejbądź pracy" "43, mieli w nim zagwarantowaną całodobową opiekę z wyżywieniem (zobacz cytat: „Starcy wstają o godzinie 7 rano, dostają na śniadanie kawę z mlekiem, bułki lub chleb smarowany; obiad o godzinie 11.30 [...]"44; nowego zakładu z napisem „Dar Kupiectwa Poznańskiego” (1935 rok), w którym umieszczano „starców i żebraków niezdolnych do pracy i nie posiadających krewnych, którzy by mogli ich utrzymać" ${ }^{45}$; przygotowanie Izby Zatrzymań w Poznaniu (1938 rok), w której mieli przebywać nieletni schwytani przez policję na żebractwie, włóczęgostwie, nielegalnym handlu itp. ${ }^{46}$.

Uwarunkowania prawne lat dwudziestych XX wieku przyczyniły się do stwierdzania stanu majątkowego ujętego żebraka, na podstawie którego określano sytuację społeczną danego człowieka (czy posiada dobrze usytuowaną rodzinę, nieruchomości na prowincji ${ }^{47}$ ). Jeśli żebractwo, które uprawiał zatrzymany, miało potwierdzenie w jego podeszłym wieku lub w braku zdolności do pracy, to gwarantowano mu wsparcie z tytułu opieki społecznej (Wydziału Opieki Społecznej) lub/i umieszczenie w zakładach dla starców ${ }^{48}$. Gdyby nałogowo żebrzący był zdolny do pracy, wówczas sądy skazywały go na pobyt $\mathrm{w}$ domu pracy przymusowej ${ }^{49}$, z wyjątkiem osób nieletnich. Takie traktowanie osób pragnących z żebractwa uczynić swój zawód nie znajdowało wprawdzie akceptacji społecznej, ale w wyniku pracy - pracy przymusowej jako czynnika

42 H. Markiewiczowa, Rozwój społecznej działalności opiekuńczej na ziemiach polskich..., dz. cyt., s. 278.

${ }_{43}$ W. Fidler, Historia Miejskiego Komitetu Walki z Żebractwem..., dz. cyt., s. 20.

44 W. Fidler, Historia Miejskiego Komitetu Walki z Żebractwem..., dz. cyt., s. 21.

45 W. Fidler, Historia Miejskiego Komitetu Walki z Żebractwem..., dz. cyt., s. 22.

46 Okólnik nr 21, z 20 stycznia 1938, w: AAP, KA 14993, Izba Zatrzymań w Poznaniu.

47 W. Fidler, Historia Miejskiego Komitetu Walki z Żebractwem..., dz. cyt., s. 25.

48 W. Fidler, Historia Miejskiego Komitetu Walki z Żebractwem..., dz. cyt., s. 27.

49 W. Fidler, Historia Miejskiego Komitetu Walki z Żebractwem..., dz. cyt., s. 27; zob. nt. żebractwa wśród nieletnich, w: R. Suchenek, Instytucje kościelne w Poznaniu wobec żebractwa dzieci na przełomie XIX i XX wieku, w: „Język - Szkoła - Religia” X (2015), nr 3. 
socjologizującego miało przywrócić jednostkę społeczeństwu, dając jej szansę moralnie akceptowalnych zachowań.

Pod koniec XX wieku i na początku XXI problem żebractwa i żebraków w miejscach publicznych nie został rozwiązany. Współczesnych żebrzących poddaje się obserwacjom, badaniom, chcąc zrozumieć powody ich wyborów takiej formy egzystencji (zobacz badania Kazimiery Król ${ }^{50}$ ). Wchodząc w dialog $\mathrm{z}$ „ludźmi luźnymi”, posiadając wiedzę na temat istoty żebractwa jako formy życia na marginesie społecznym $\mathrm{z}$ własnego wyboru ${ }^{51}$ lub z innego powodu bliżej nieznanego, w początkach XXI wieku przedstawiciele organizacji społecznych i kościelnych niosą pomoc potrzebującym, jak również uświadamiają poszczególne grupy społeczne nt. zagrożeń wynikających ze wspomagania tzw. zawodowych żebraków (wpisujących się swoimi zachowaniami w określenie „pasażerowie na gape") - np. badania prowadzone przez Instytut Filozofii, Socjologii i Dziennikarstwa Uniwersytetu Gdańskiego, z których wynika, że 75-80 procent „osób żebrzących na ulicach Trójmiasta to tzw. żebracy zawodowi” ${ }^{52}$. Inną formą docierania do społeczeństwa $\mathrm{z}$ informacjami nt. zawodowych żebraków są kampanie prowadzone w miastach, np. w spotach emitowanych w środkach komunikacji miejskiej (Kraków), poprzez plakaty promujące akcje przeciwko żebractwu (Poznań) ${ }^{53}$, wydawanie broszur (zob. broszura pt. Handel ludźmi $w$ Polsce $\left.^{54}\right)$. Odmienny typ informacji nt. niewspierania żebraków można znaleźć na stronach internetowych instytucji, w których, jak w tej poniżej zacytowanej, potencjalni ofiarodawcy zostają uwrażliwieni na jakość niesionej pomocy i konsekwencje jej udzielania - „Dając pieniądze żebrakom, nie pomagasz, tylko szkodzisz! Jeśli żebrak dostanie pieniądze, to nie skończy z tym, tylko dalej będzie robić to, co opłacalne. Nakręcając ten biznes, m.in. stawiasz wille ludziom, którzy zarządzają mafiami żebraków. [...] Wydrukuj i podaj żebrakowi listę poniższych adresów zamiast pieniędzy. Dzięki niej dostanie jedzenie, schronienie, ewentualną pomoc medyczną, a także zasiłek czasowy oraz możliwość korzystania z kursów, szkoleń, stażów itd."55.

$50 \quad$ K. Król, Żebractwo we wspótczesnej Polsce..., dz. cyt., s. 15-16.

51 Zob. opracowania na temat żebractwa, wyżej cytowane: B. Geremka, K. Król, S. Marmuszewski, J. Światłowski.

${ }_{52}$ R. Borowski, Chcesz pomóc żebrzącym? Nie dawaj mu pieniędzy, w: http://www. trojmiasto.pl/wiadomosci/Chcesz-pomoc-zebrzacemu-Nie-dawaj-mu-pieniedzy-n89674. html (14.12.2016).

53 D. Majewska, Nie dawaj pieniędzy na ulicy! - nawołują urzędnicy. Tylko co im do tego, na co przeznaczam piątaka, w: http://natemat.pl/145767, nie-dawaj-pieniedzy-na-ulicy-nawoluja-urzednicy-tylko-co-im-do-tego-na-co-przeznaczam-piataka (14.12.2016).

54 Handel ludźmi w Polsce, opracowanie Ministerstwo Spraw Wewnętrznych. Przygotowano w ramach realizacji Krajowego Planu Działania przeciwko Handlowi Ludźmi na lata 2013-2015.

55 „Uważaj, komu dajesz swoje pieniądze. Pomagaj naprawdę”, w: http://pokazywarka. $\mathrm{pl} /$ zebracy/ (15.12.2016). 
Kierując się zasadą partnerstwa ${ }^{56}$, instytucje państwowe (na poziomie ministerialnym, samorządowym itp.) i non-profitowe (np. Związek Organizacji Sieć Współpracy Barka ${ }^{57}$ ) przekazują sobie nawzajem dobre praktyki walki o wykluczonych, w tym o osoby będące żebrakami (żebrakami żebrzącymi pod presją czyjąś, np. w szerokiej perspektywie - organizacji handlującej ludźmi, czy też $\mathrm{w}$ bliskiej relacji - rodzicami nieletnich dzieci ${ }^{58}$ ). Ponadto informują potrzebujących o możliwościach uzyskania pomocy kierowanej do nich (za pomocą broszur, przy udziale wolontariuszy itp.). Wchodząc w relacje dialogowe, starają się dbać o dobro społeczne pokrzywdzonych (żebraków z konieczności, żebraków pracujących dla kogoś) i całej reszty społeczeństwa (przed żebrakami zawodowymi $)^{59}$.

Podobnie, jak w poprzednich okresach, oferuje się żebrakom pomoc świecką, kościelną, organizacji rządowych i pozarządowych, np. fundacji (zob. Fundacja Pomocy Wzajemnej „Barka” w Poznaniu), towarzystw (np. Towarzystwa Pomocy im. św. Brata Alberta w Gdańsku, w Krakowie itp. ${ }^{60}$ ). Do działań na rzecz osób wykluczonych społecznie, a żyjących z żebractwa (z konieczności) można zaliczyć przeciwdziałanie na rzecz dehumanizacji żebraka, dawanie wolnego wyboru w wyborze przez żebraka np. miejsc noclegowych, miejsc spożywania posiłków, udzielanie pomocy specjalistycznej, np. wzywanie pomocy medycznej do żebraków chorych. Szczególnym rodzajem pomocy jest stwarzanie miejsc pracy dla potrzebujących, oferty edukacyjnej, które podnoszą jakość życia, wracają społeczeństwu człowieka świadomego swoich praw i obowiązków. Inny typ pomocy okazywanej przez organizacje pozarządowe skupia się na zapewnianiu terapii psychologicznej, pedagogicznej, socjologicznej, czy też terapii uzależnień (od alkoholizmu, narkomanii), które towarzyszą żebrakom ${ }^{61}$.

Wszystkie bardziej bądź mniej wyspecjalizowane sposoby pomocy wpływają na życie „ludzi luźnych”. Powodują upodmiotowienie żebraków i dają szansę

\footnotetext{
56 J. Damon, Wykluczenie, tłum. A. Karpowicz, Warszawa 2012, s. 78n.

57 Standardy w pomocy, w: http://siecbarka.pl/standardy-w-pomocy/ (15.12.2016).

58 Zob. nt. współczesnych praktyk wykorzystywania dzieci do żebractwa oraz nt. przekazywania informacji o nieletnich żebrzących, w: Handel ludźmi w Polsce, opracowanie Ministerstwo Spraw Wewnętrznych...., dz. cyt., s. 31-32.

59 Problem obecności natrętnych żebraków jest wciąż obecny na ulicach miast Polski, o czym na bieżąco przekazują informację portale społecznościowe, lokalna prasa; zob. np. T. Kapica, Żebracy i bezdomni. Cuchna, piją, zaczepiaja innych, w: http://www.nto.pl/ wiadomosci/kedzierzyn-kozle/art/9369841,zebracy-i-bezdomni-cuchna-pija-zaczepiaja-innych,id,t.html (15.12.2016).

${ }_{60}$ Zob. więcej nt. Towarzystwa Pomocy im. św. Brata Alberta, w: http://www.bratalbert. org/ (15.12.2016).

${ }_{61}$ B. Pietkiewicz, Monar: historia pewnego blaszaka. Słońce moje, wytrwaj, w: http:// www.polityka.pl/tygodnikpolityka/spoleczenstwo/1501377,1,monar-historia-pewnego-blaszaka.read (14.12.2016).
} 
ich resocjalizacji, dowartościowania się w perspektywie człowieczeństwa, powtórnego „zakorzenienia” w rodzinach, społeczności lokalnej ${ }^{62}$. Takie zespolone działania prowadzą $\mathrm{w}$ duchu Ewangelii i praw prospołecznych przykładowo do powrotu do zdrowia psychicznego, zaakceptowania swej inności, odbudowy życia ludzi, którym przyszło żebrać o pomoc w wyniku utraty pracy, rodziny, zdrowia ${ }^{63}$.

Porozumiewanie między przedstawicielami społeczeństwa ukształtowanego na zasadzie personalistycznych relacji, praworządności, uczciwości wykazywanej w zasadach etyki z ludźmi marginesu, w tym z żebrakami, musi nastręczać problemy wynikające $\mathrm{z}$ różnych płaszczyzn kulturowo-socjologicznych. Przełamywanie różnic między przedstawicielami społeczeństwa a podgrupami - ludźmi marginesu tkwi w najbardziej podstawowych potrzebach życia ludzkiego, do których przede wszystkim zalicza się potrzeby: fizjologiczne, bezpieczeństwa, uznania ${ }^{64}$. Te uwarunkowania osobnicze próbują w praktyce niwelować, biorąc pod uwagę dobro każdego człowieka, teoretycy (filozofowie dialogu, psychologowie itp.), jak i praktycy (osoby zaangażowane w prace społeczno-socjalne, charytatywne). Dążenia jednych i drugich nastawione na dialog międzyludzki o charakterze społeczno-etycznym prowadzą do otwarcia się na spotkanie z drugim człowiekiem i „doświadczenia drugiego człowieka” ${ }^{65}$.

Jedną z zasad wprowadzających dialog nastawiony na innego jest zaakceptowanie go jako człowieka w perspektywie chrześcijańsko-humanitarnej, który, łamiąc zasady społecznie akceptowane, nie zasługuje na potępienie i wydalenie ze społeczności na jej margines. Innym przyczynkiem do prowadzenia społecznego dialogu $\mathrm{z}$ innym-żebrakiem jest niesienie mu pomocy na zasadzie wzajemnego szanowania zasad ustalonych, które z założenia gwarantują powrót wykluczonego do społeczeństwa (co poświadczają doświadczenia organizacji non-profit).

Dzięki permanentnej relacji, jaką wytwarza dialog pomiędzy przedstawicielami różnych części społeczeństwa a jego marginesem, wytwarza się bliskość idei, potrzeb, odniesień. Wspólnota potrzebujących i tych, którzy są otwarci na problemy pierwszych, w wyniku spotkań tworzy społeczność gotową do okazywania zrozumienia i szacunku wobec inności, dostrzegania w innych prawdy o człowieczeństwie i piękna w czynieniu dobra.

${ }^{62}$ Zob. działania w ramach Barki Fundacji Pomocy Wzajemnej, w: Wspólnoty Barki, w: http://barka.org.pl/node/120 (15.12.2016).

${ }_{63}$ Zob. Historie ludzi, którzy w naszych domach odnaleźli swoja drogę do normalnego życia, w: http://www.bratalbert.org/pomoglismy-im.html (14.12.2016).

${ }^{64}$ Podstawowe potrzeby ludzkie zaproponował Abraham Maslow (zob. Piramida potrzeb ludzkich według Maslowa).

65 Zob. A. Bronk, A, Salamucha, Dialog jako droga do prawdy o człowieku..., dz. cyt., s. 23. 


\section{Bibliografia}

Abramowicz B., Dialog społeczny w Polsce - instytucjonalizacja i praktyka, w: „Ruch prawniczy, ekonomiczny i socjologiczny" LXXI (2009), z. 4, s. 225-244.

Barańska B., Eichner M., Hus K., Dialog społeczny i tworzenie partnerstw na rzecz rynku pracy, Katowice 2011.

Bronk A., Salamucha A., Dialog jako droga do prawdy o człowieku, w: „Paedagogia Christiana” 25 (2010), nr 1, s. 11-32.

Buber M., Ja $i$ Ty. Wybór pism filozoficznych, Warszawa 1992.

Czytania Bractwa Miłosierdzia w Krakowie przy kościele Św. Barbary z dodatkiem Kazań o Miłosierdziu przez ks. Piotra Skarge, Kraków 1896, s. 225-251.

Damon J., Wykluczenie, tłum. A. Karpowicz, Warszawa 2012.

Jan Paweł II, Encykliki Ojca Świętego Jana Pawła II, Kraków 2009.

Kwaśniewicz W., Encyklopedia socjologii, t. 2, Warszawa 1999.

Fidler W., Historia Miejskiego Komitetu Walki z Żebractwem w Poznaniu, Poznań 1937.

Frieske K.W., Dialog społeczny i demokracja, w: Dialog społecznych na poziomie regionalnym. Ocena szans rozwoju, red. D. Zalewski, Warszawa 2005.

Geremek B., Ludzie marginesu w średniowiecznym Paryżu XIV-XV wiek, Poznań 2003.

Geremek B., Świat „opery żebraczej”. Obraz włóczęgów i nędzarzy w literaturach europejskich XV-XVII wieku, Warszawa 1989.

Górzna S., „Inny” w filozofii Emmanuela Levinasa, w: „Słupskie Studia Filozoficzne” 2012, nr 11, s. 57-70.

Grzybowski A., Szpitale dziewiętnastowiecznego Poznania, w: Kronika Miasta Poznania. Szpitale, Poznań 2007, nr 4, s. 40-46.

Handel ludźmi w Polsce, opracowanie Ministerstwo Spraw Wewnętrznych. Przygotowano w ramach realizacji Krajowego Planu Działania przeciwko Handlowi Ludźmi na lata 2013-2015.

Karpiński A., Historycy wobec marginesu społecznego w Polsce XVI-XVIII wieku, w: Artykuły recenzyjne i recenzje, w: „Kwartalnik Historyczny” 1987, nr 2, s. 177-188.

Komarynska-Polak H., Psychicznie chorzy w krakowskim szpitalu bonifratrów w XVII-XVIII wieku, w: Zeszyty Naukowe Małopolskiej Wyższej Szkoły Ekonomicznej w Tarnowie, t. 18, 2011, nr 1, s. 33-46.

Król K., Żebractwo we współczesnej Polsce jako kwestia społeczna, Konin 2010.

Kubicki R., Trudny język spotkania, w: Dialog w żywiole wyobraźni, red. J. Stranz, Poznań 2008, s. 110-115 (Wyobraźnia dialogu, 1)

Łukaszewicz J., Śpitale i inne dobroczynne zakłady i fundusze, w: Kronika Miasta Poznania. Szpitale, Poznań 2007, nr 4, s. 19-34. 
Markiewiczowa H., Rozwój społecznej działalności opiekuńczej na ziemiach polskich, w: „Seminare” 28 (2000), s. 273-284.

Marmuszewski S., Światłowski J., Rola żebracza i jej ekspresja, w: Żebracy w Polsce, red. S. Marmuszewski i A. Bukowski, Kraków 1995, s. 122-154.

Nowak M., Dialog w wychowaniu, w: „Paedagogia Christiana” 25 (2010), nr 1, s. 85-103.

Stawnicka-Zwiahel E., Człowiek wiary-godny w filozofi spotkania Martina Bubera, w: „Nauka - Etyka - Wiara" 2011, s. 359-376.

Suchenek R., Instytucje kościelne w Poznaniu wobec żebractwa dzieci na przełomie XIX i XX wieku, w: „Język - Szkoła - Religia” 2015, nr 3, s. 37-50.

Sztumski J., Systemowa analiza społeczeństwa, Katowice 2013.

Tarnowski J., Pedagogika dialogu, w: Edukacja alternatywna. Dylematy teorii i praktyki, red. B. Śliwerski, Kraków 1992, s. 112-122.

Tischner J., Nadzieja czeka na słowo. Rekolekcje 1966-1996, Kraków 2011.

Borowski R., Chcesz pomóc żebrzacym? Nie dawaj mu pieniędzy,

http://www.trojmiasto.pl/wiadomosci/Chcesz-pomoc-zebrzacemu-Nie-dawaj-mupieniedzy-n89674.html (14.12.2016).

Historie ludzi, którzy w naszych domach odnaleźli swoją drogę do normalnego życia, http:// www.bratalbert.org/pomoglismy-im.html (14.12.2016).

Kapica T., Żebracy i bezdomni. Cuchną, piją, zaczepiają innych,

http://www.nto.pl/wiadomosci/kedzierzyn-kozle/art/9369841,zebracy-i-bezdomni-cuchna-pija-zaczepiaja-innych,id,t.html (15.12.2016).

Majewska D., Nie dawaj pieniędzy na ulicy! - nawołuja urzędnicy. Tylko co im do tego, na co przeznaczam piątaka, http://natemat.pl/145767,nie-dawaj-pieniedzy-na-ulicy-nawoluja-urzednicy-tylko-co-im-do-tego-na-co-przeznaczam-piataka (14.12.2016).

Pietkiewicz B., Monar: historia pewnego blaszaka. Słońce moje, wytrwaj,

http://www.polityka.pl/tygodnikpolityka/spoleczenstwo/1501377,1,monar-historia-pewnego-blaszaka.read (14.12.2016).

Sionek A., Nic nam nie odbierze radości głoszenia, s. 1-35, http://www.enchristo.pl/wp-content/uploads/2014/05/Nic_nam_nie_odbierze_radosci_gloszenia_Andrzej_Sionek_refleksja_nad_Evangellii_Gaudium.pdf (27.11.2016).

Standardy w pomocy, http://siecbarka.pl/standardy-w-pomocy/ (15.12.2016).

Towarzystwa Pomocy im. św. Brata Alberta, http://www.bratalbert.org/

„Uważaj, komu dajesz swoje pieniądze. Pomagaj naprawdę”, http://pokazywarka.pl/zebracy/ Wspólnoty Barki, http://barka.org.pl/node/120 (15.12.2016).

Archiwum Akt Nowych Ministerstwo Opieki Społecznej:

sygn. 54, Zwalczanie żebractwa i włóczęgostwa. Projekt ustawy 1925

Archiwum Archidiecezjalne w Poznaniu (AAP):

KA 14993, Izba Zatrzymań w Poznaniu 
KA 15055, Akta schronisk - przytułków

OA VIII 23, Stowarzyszenie przeciw żebractwu i kolonia robocza w Laskach Starych 1862-1893

Archiwum Państwowe w Krakowie, ZC, sygn. 71, Oświęcim

Archiwum Państwowe w Poznaniu:

Akta miasta Poznania

sygn. 3980, Statystyka. Opieka nad ubogimi

Akta miasta Środy

sygn. 1447, Żebractwo i włóczęgostwo 